\title{
6.9 Наукові аспекти використання уронатних полісахаридів у технології харчової продукції
}

На сьогоднішній день відомо, що глюкуронова кислота володіє широким спектром властивостей та фізіологічних особливостей, спрямованих в тому числі і на детоксикуючий ефект. Суттєвим є вивчення і природних речовин, до складу яких входить глюкуронова кислота: ксантан, гліциризин, гіалуронова кислота, 3 метою реалізації їх фізико-технологічних властивостей у складі композиційних гідрогелей, як основи широкого спектру продуктів для здоров'я людини (продукти харчування, фармацевтичні, лікарські, косметичні засоби).

Широкий спектр виробництва харчової продукції базується на модифікаціях якісного та варіаціях кількісного складу готового продукту. Адаптація технологій харчової продукції до сучасного обладнання та існуючих потреб споживачів вимагає поглибленого наукового вивчення, оскільки процеси недостатньо обгрунтовані.

На сьогоднішній день у світі досить ефективно застосовуються уронатні полісахариди. Ці важливі природні комплекси використовуються як для харчових, так і для технічних цілей. Значного практичного значення дані сполуки набувають завдяки біологічній активності та використанню як детоксикаторів іонів важких металів.

Тому, розуміння характеристик рослинної сировини, яка містить уронові кислоти, аналіз щодо об’єктивного вибору видів уронатних полісахаридів для промислової переробки, його фізико-хімічних властивостей сприяють ефективному практичному значенню координаційної взаємодії таких комплексів iз подальшим проявом їх технологічного та фізіологічного ефектів. 
SCIENTIFIC FOUNDATIONS OF SOLVING ENGINEERING TASKS AND PROBLEMS

\section{Властивості уронових кислот у складі низько- та \\ високомолекулярних сполук}

Глюкуронова кислота належить до уронових кислот, що утворюється в організмі з глюкози при окисленні iї первинної спиртової групи. Одноосновна. D-глюкуронова кислота входить до складу кислих мукополісахаридів, деяких бактеріальних полісахаридів, тритерпенових сапонінів, геміцелюлози і камеді. Вільна глюкуронова кислота в невеликих кількостях знайдена в крові і сечі. У вигляді парних сполук глюкуронової кислоти (глюкуронідів) з сечею виводяться деякі продукти обміну речовин, в тому числі отруйні (фенол, крезол), і багато лікарських речовин. Перетворення глюкуронової кислоти у всіх тварин, крім мавпи і морської свинки, а також людини, ведуть до біосинтезу аскорбінової кислоти. У фізіологічних рідинах і тканинах тварин (особливо в печінці, нирках, селезінці, а також злоякісних пухлинах), в бактеріальних і рослинних тканинах міститься фермент $\beta$-глюкуронідаза, який каталізує гідроліз $\beta$-глюкуронідів на вільної глюкуронової кислоти і відповідного аглікону [407].

Функціональні групи для іонного зв'язування (-COOH) i для міжмолекулярної взаємодії (-OH) 3 іншими учасниками технологічного середовища та шлунково-кишкового тракту відображаються структурній схемі глюкуронової кислоти (рис. 1).

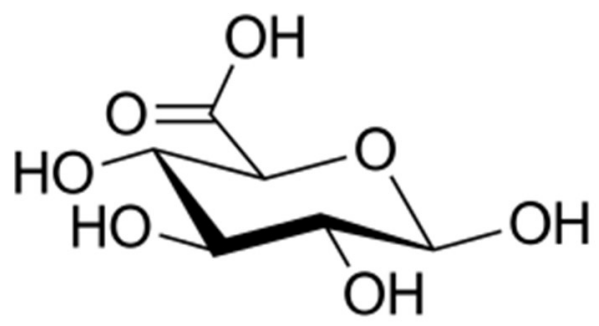

Рис. 1. Будова глюкуронової кислоти

Глюкуронова кислота зосереджена в невеликих кількостях у людському організмі, де відбувається іiі утворення при окисленні D-глюкози. Нормальна іiі концентрація в крові становить 0,02-0,08 ммоль/л. До складу слизу, слини, міжклітинного матриксу, гликокаліксу входить, зокрема глюкуронова кислота. 
SCIENTIFIC FOUNDATIONS OF SOLVING ENGINEERING TASKS AND PROBLEMS Вона є також одним із ключових компонентів пігментного обміну в печінці.

Властивості глюкуронової кислоти в певним чином збігаються 3 властивостями глюкози, проте завдяки наявності карбоксильної групи, 3'являється можливість утворення солей та лактонів. За нагрівання відбувається дегідратацію і декарбоксилювання глюкуронової кислоти.

Важливою для організму людини функцією глюкуронової кислоти є іiі здатність утворювати розчинні кон'югати (глюкуроніди) зі спиртами, фенолами, карбоновими кислотами, тіолами, амінами та низкою інших речовин. За рахунок цього вона набула статусу потужного детокс-агенту, що також здатний до лояльного виведення з організму продуктів біотрансформації.

Уронові кислоти входять до складу ряду низько- та високомолекулярних сполук, що широко використовуються як в технологічному процесі виробництва харчової продукції, так і в косметичній та фармацевтичній галузях.

Одними 3 таких є гліциризин (харчова добавка Е958) або гліциризинова кислота (GA), що широко використовується як підсолоджувач та підсилювач смаку та аромату. Гліциризин солодший за сахарозу в 50-100 разів. Його також застосовують як піноутворювач під час виробництва халви. Одним 3 найважливіших похідних GA є іï моноаммонійна сіль GC.

Хімічна будова гліциризину представлена на рис 2.

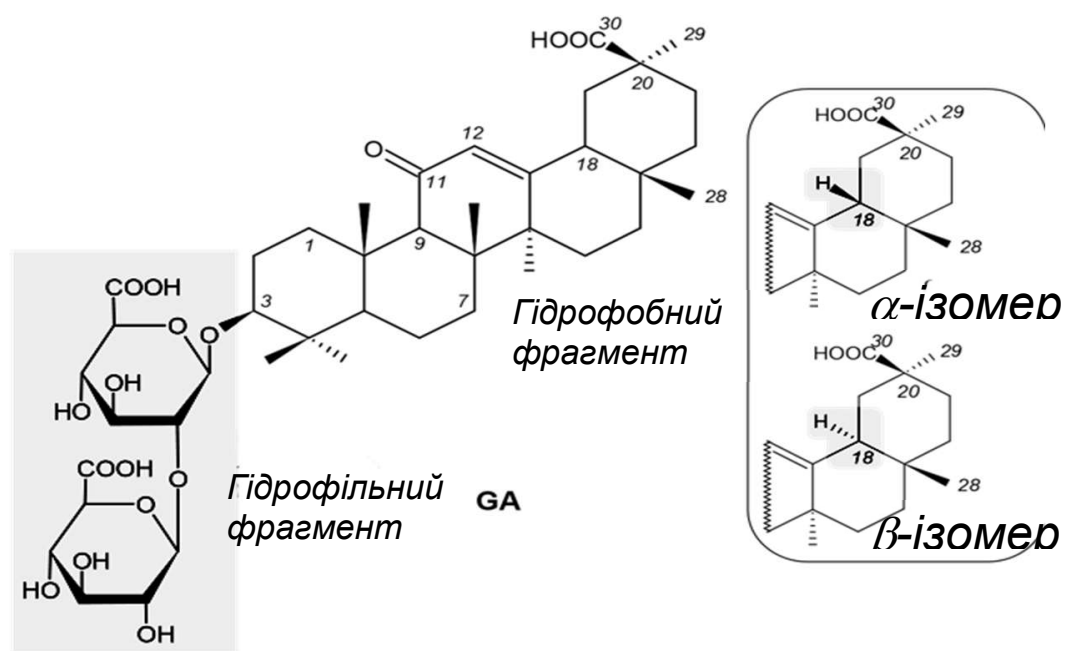

Рис. 2 Хімічна будова гліциризину 
SCIENTIFIC FOUNDATIONS OF SOLVING ENGINEERING TASKS AND PROBLEMS

Як видно з рис. 2 у структурі GA розрізняють гідрофобний фрагмент, що відповідає агліконному залишку, i гідрофільну частину, яку утворює дисахаридний фрагмент. При цьому, наявність карбоксильної груп в кільці аглікона і в термінальному залишку дисахаридного фрагмента вуглеводного ланцюга обумовлює здатність GA до утворення різних самоасоціатів, які набувають стабільності за рахунок утворення водневих зв'язків [408].

Характерною особливістю GA і iї солей є здатність до утворення міцел. Міцелоутворення GA залежить від складу середовища та ï кислотності. Предміцелярні форми утворені двома і більше молекулами GA.

Таким чином, GA належить до амфіфільних полідентатних лігандів, здатних до молекулярного комплексооутворення як $з$ полярними, так і неполярними фрагментами молекул інших речовин. Для молекул GA характерне утворення циклічних асоціатів 3 внутрішньою гідрофобною порожниною, яку можуть займати різні співмірні молекули з метою створення комплексів типу «гістьгосподар» (рис.3) [409].
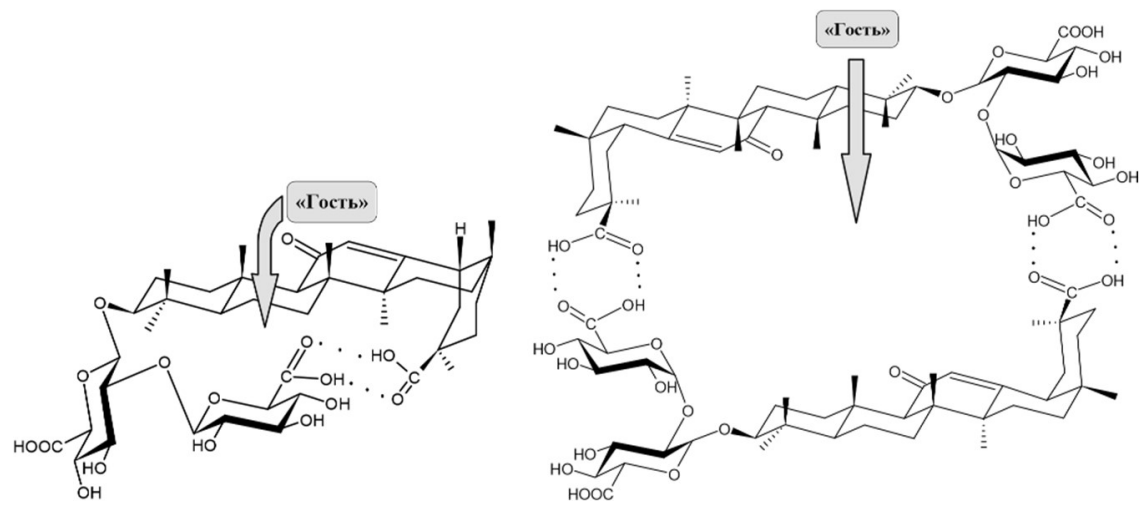

Рис 3 Структура асоціатів димерів гліциризину

Як видно з рис. 3, саме шляхом реалізації принципу "гість-хазяїн", у димері гліциризину і пояснюється детокс-ефект цієї речовини.

Ксантан - молекулярний полісахарид, основний ланцюг якого побудований аналогічно целюлозі (1-4- $\beta$-глікопіраноза), а бічний - представлений у вигляді трисахариду, який складається з $\beta$-D-манози, $\beta$-D-глюкуронової кислоти i $\alpha$-D- 
SCIENTIFIC FOUNDATIONS OF SOLVING ENGINEERING TASKS AND PROBLEMS манози. Залишки глюкуронової кислоти і кислі піровиноградні групи надають молекулам ксантану аніонного характеру

Ксантан переважно застосовується в харчовій та косметичній промисловості як загусник та гелеутворювач.

Гідрогелі на його основі - це в'язкі розчини навіть при дуже низьких концентраціях. При збільшенні концентрації вони перетворюються на напівпрозорі аморфні речовини. Глікозидні зв'язки у структурі ксантану гідролізуються під впливом кислот і специфічних ферментів відділу кишечника.

Унікальні біологічні та реологічні властивості ксантану багато в чому визначаються впорядкованою будовою його ланцюгів в розчинах. Ксантан, як високомолекулярна сполука, має первинну, вторинну i вищу просторову структуру. Це обумовлено слабкими внутрішньомолекулярними взаємодіями, серед яких основну роль відіграють водневі зв'язки і вандерваальсові сили. Хімічна будова ксантану представлена на рис 4.

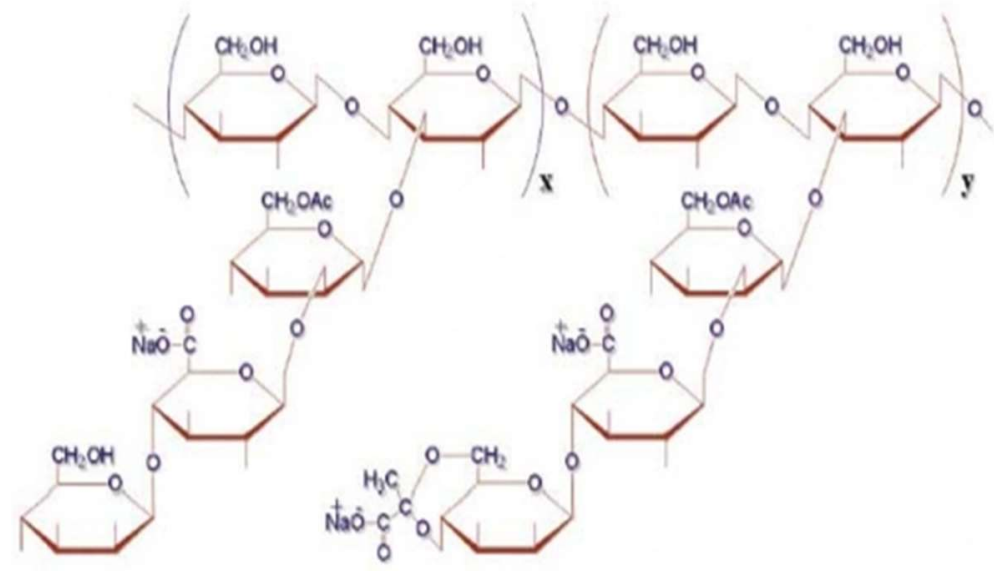

Рис. 4 Первинна структура мікробного екзополісахариду ксантану

Як видно з рис.4, просторова будова ксантану приховує частину функціональних груп глюкуронової кислоти, перешкоджає взаємодії 3 ксенобіотиками/лікарськими засобами/біологічно активними речовинами. Це зумовлює у ксантана відсутній детокс-ефект, принаймні у відділі шлунку. При потраплянні до відділів ШКТ за рН вище 7, третинна структура ксантану руйнується, бічні ланцюги розгортаються, відштовхуючись від основного 
SCIENTIFIC FOUNDATIONS OF SOLVING ENGINEERING TASKS AND PROBLEMS ланцюга під дією іонної сили розчинника (води), і надають можливості глюкуроновій кислоті утворити хімічний зв'язок з іншими речовинами. Такими у кишківнику $\epsilon$ важкі метали, продукти напіврозпаду макронутрієнтів, радіонукліди, токсини.

Гіалуронова кислота - несульфатований глікозаміноглікан, нерозгалужений полісахарид, що складається 3 дісахаридних одиниць, утворених N-aцетил-Dглюкозаміном і D-глюкуроновою кислотою, які з'єднані між собою $\beta$ - 1,3 - i $\beta$ - 1,4 глікозидними зв'язками (рис. 5) [410].

Гіалуронова кислота - це аніонний лінійний полісахарид 3 різною молекулярною масою 105-107 Да. Молекулярна маса залежить від способу одержання. При цьому, зважаючи на відсутність ізомерії, одержуваний гіалуронат завжди хімічно ідентичний стандартному.

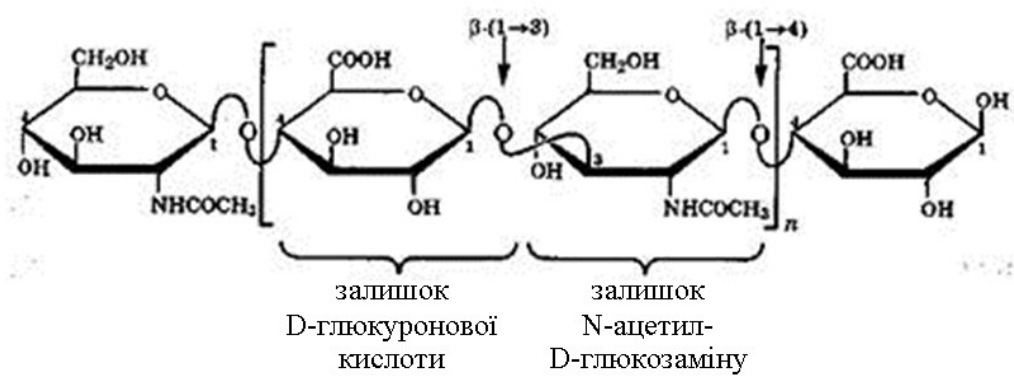

Рис. 5 Хімічна будова гіалуронової кислоти

Як видно з рисунку 5, молекулам гіалуронової кислоти притаманне утворення значної кількості водневих зв'язків, як зсередини молекули, так і між сусідніми вуглеводними залишками, які розміщуються дистанційно віддалено один від одного, а у водному розчині навіть між близько розташованими молекулами через карбоксильну та ацетамідну групу [411].

Розчини гіалуронової кислоти - це розчини полімерів із кислою реакцією середовища через наявність непротонованої карбоксильної групи. Кислотні властивості гіалуронатів дозволяють отримувати у водному середовищі розчинні солі з лужними металами.

Розчини гіалуронової кислоти у концентрації 1..4\% утворюють псевдогелі, як і розчини ксантану. 
SCIENTIFIC FOUNDATIONS OF SOLVING ENGINEERING TASKS AND PROBLEMS

Гідрогелі гіалуронової кислоти володіють унікальними реологічними властивостями в'язкопружного гелю навіть при низьких концентраціях. Методом світорозсіювання було встановлено, що в розчині макромолекула згорнута у катушку (спіраль). Ланцюг досить щільно упакований з радіусом вигину порядку 200 нм і малорухливий (3-за наявності внутриланцюгових водневих зв'язків).

Молекула гіалуронової кислоти у водному розчині $є$ енергетично стабільною, зокрема завдяки стереохімії складових іiі дисахаридів. Об'ємні заміщувальні групи піранозного кільця стерично вигідно розташовані, тоді як менші за розміром атоми водню займають менш вигідні аксіальні позиції.

Так само, як і у випадку з ксантаном, за рахунок міжмолекулярних взаємодій довгі гнучкі молекули гіалуронової кислоти у водних розчинах здатні утворювати тривимірну структуру, подібну до щільного молекулярного «сита» - матрикса. При цьому дисперсний матрикс утворює канальці для селективної дифузії водорозчинних молекул. У макромолекулі регулярно повторюються гідрофобні області, що сприяють взаємодії з клітинними мембранами і білками гідрофобного типу. Така властивість розчинів гіалуронової кислоти має велике значення для забезпечення рухливості клітин. Гідрофільний дисперсний матрикс забезпечує умови протікання дифузійних процесів, необхідних для клітинного дихання.

Уронові кислоти входять також до складу полісахаридів, зокрема пектину та альгінатів. Їх властивості та подальше застосування обумовлене низкою визначальних факторів - походженням, хімічною будовою тощо.

Їх диференціювання відбувається залежно від природи, реакційних груп, молекулярної маси, активної концентрації, необхідної для гелеутворення.

\section{Роль гідрогелевих уронових систем в організмі людини}

На сьогоднішній день полімерні гідрогелі на основі композитів, до складу яких входит глюкуронова кислота, володіють рядом унікальних механічних, 
SCIENTIFIC FOUNDATIONS OF SOLVING ENGINEERING TASKS AND PROBLEMS фізико-хімічних та фізіологічних особливостей. Це зумовлює перспективність їх застосування у фармацевтиці, медицині та інших галузях.

Зокрема, використання гідрогелів на основі ксантану, гліциризину та гіалуронової кислоти, як лікарської форми, забезпечує пролонгування дії лікарської сполуки, адресну доставку до систем і органів-мішеней, а в деяких випадках і помітний синергетичний ефект дії препарату і фармакопейної основи. Крім того це призводить до зниження токсичності препаратів, їх побічних ефектів, зменшення їх дози при збереженні високої біологічної активності за рахунок вмісту гліциризину.

У випадку доставки біологічно активних речовин із високою реакційною здатністю у відділах шлунку, в якості іммобілізуючої для них матриці виступають структури ксантану та гіалуронової кислоти. В них глюкуронова кислота міжмолекулярними та водневими зв'язками утримує корисні молекулярні структури. При цьому, низькомолекулярні структури утримуються у міжмолекулярному просторі гліциризину та гіалуронової кислоти, а більш об'ємні молекули, утримуються за рахунок зв'язків з функціональними групами ксантану.

Гліциризинова кислота володіє здатністю до утворення асоціатів у розчинах. Це пояснюється значною кількістю оксигеновмісних полярних груп. Саме завдяки наявності цих груп гліциризинова кислота проявляє високу хімічну активність до зв'язування молекул, як лікарських так і токсичних сполук [412].

У першому випадку, лікарські засоби міжмолекулярними силами утримуються у матриці гідрогелю на основі гліциризину і тимчасово втрачають свою хімічну активність, далі, знаходячись в іммобілізованому стані, утворені інтактні сполуки дістаються до органів-мішеней і вивільняються у місцях їх всмоктування за рахунок руйнації полімерних молекул, що відбувається при переході $\mathrm{pH}$ у нейтрально-лужне середовище. У такий спосіб відбувається i доставка біологічно активних речовин 3 високим хімічним потенціалом у середовищі шлунку, але місцем всмоктування у кишківнику. Спосіб попередньої 
SCIENTIFIC FOUNDATIONS OF SOLVING ENGINEERING TASKS AND PROBLEMS іммобілізації глюкуроновою кислотою дозволяє зберегти молекулярні структури корисних речовин і у непошкодженому стані довести їх до місць засвоєння, завдяки чому у одній мікродозі мітиться достатня кількість біологічно активних речовин для покращення метаболізму в організмі людини.

За даними Всесвітньої організації охорони здоров’я, гліциризинова кислота застосовується як заспокійливий засіб при лікуванні ангіни та відхаркувальний засіб при кашлы та катарі верхніх дихальних шляхів. Вона також відіграє вирішальну роль у профілактиці та лікуванні виразки шлунку та дванадцятипалої кишки, а також диспепсії. Як протизапальний засіб зменшує алергічні реакції та запобігає токсичності печінки [413].

Істотну роль комплекси гліциризнової кислоти відіграють як протипухлинні засоби. Авторами [414] встановлено суттєве пригнічення росту клітин раку легенів in vitro та у тканинах мишей.

Натуральні комплекси на основі гліциризинової кислоти вже понад 40 років широко використовуються в Японії при лікуванні захворювань печінки, зокрема хронічного гепатиту [415]. Відомою $є$ практика застосування природних комплексів гліциризинової кислоти у лікуванні захворювань шкіри [416], зокрема псоріазу [417]

На користь гліциризинової кислоти та ії антикоронавірусного потенціалу схиляються дослідники [418].

Препарати з гліциризиновою кислотою є безпечними та володіють гарним економічним профілем. За останні роки збільшується їх клінічне використання, зокрема при таких патологіях, як депресія [419], хвороба Паркінсона [420], а також ряду онкологічних захворювань [421].

Реологічні властивість ксантанової камеді $є$ важливим фактором для розробки біоматеріалів, які можуть бути використані для поліпшення доставки ліків або інших корисних речовин у зони з низькою проникністю, інжектування гідрогелями для біомедичних застосувань, у тому числі і в тканинній інженерії. 
SCIENTIFIC FOUNDATIONS OF SOLVING ENGINEERING TASKS AND PROBLEMS

Також відомим є застосування при цукровому діабеті, закрепах, сухості очей та багатьох інших патологічних станах [422].

Під час моделювання процесу травлення людини ксантанова камедь знижувала концентрацію глюкози, не впливаючи негативно на товщину травної рідини [423]. Автори [424] відмічають широке застосування ксантану як замінника слини при ксеростомії. Дослідниками [425] встановлено полегшення перебігу дисфагії - розладів, що викликають труднощі 3 ковтанням, при вживанні ксантану.

Серед деяких рекомендацій при лікуванні ожиріння, зустрічаються препарати ксантану, як такого, що викликає відчуття насиченості та знижує апетит [426].

Ксантанова камедь широко використовується з метою утворення захисного бар’єру над зубами та таким чином блокуючи атаки кислоти 3 продуктів харчування на зубну емаль, попереджаючи її руйнування [427].

Загальновідомо, що гіалуронова кислота бере участь у контролі таких процесів, як репаративна регенерація тканин, клітинне диференціювання, морфогенез, ангіогенез і запалення. Важливість участі гіалуронової кислоти у цих процесах грунтується на іiі феномені, що реалізується під час створювання гідрогелів. Якщо питання стосується міжклітинного матриксу, то гіалуронова кислота набухає з утворенням каркасних гелевих структур і підтримує клітини. Оскільки гіалуронова кислота це єдиний глікозаміноглікан, який не утворює ковалентного зв'язку 3 білковим кором (тобто не існує протеоглікану гіалуронової кислоти), то у водних розчинах реалізується можливість концентрувати навколо себе інші глікозаміноглікани з утворенням агрегатів протеогліканів, що володіють значно більшою гідрофільністю та еластичністю порівняно з подібними структурами, але у вільному стані. У зв'язку з цим стає зрозумілим феномен гіалуронової кислоти, що пов'язаний iз властивістю зв'язування колагенових волокон, інших білків, компонентів міжклітинного матриксу між собою та клітин у єдину систему. У такий спосіб гіалуронова 
SCIENTIFIC FOUNDATIONS OF SOLVING ENGINEERING TASKS AND PROBLEMS кислота створює «буферний об'єм», який визначає міцність і пружність механічних тканин, допомагає їм долати тимчасові навантаження [428].

Гіалуронова кислота сприяє зниженню негативного впливу на шкіру ультрафіолетового проміння, тютюнового диму та навколишнього середовища [429]. Вживання від 120 до 240 мг гіалуронової кислоти в день протягом місяця сприяє підвищенню рівня зволоженості шкіри та сповільнює процеси старіння [430].

Гіалуронова кислота також відіграє ключову роль у процесі загоєння ран. В нормальному стані вона присутня у шкірі, та їі концентрація підвищується при ураженні та потребі у відновленні. Вона сприяє більш швидкому загоєнню ран заживати, регулюючи рівень запалення і подаючи сигнал організму до побудови більшої кількості судин у пошкодженій області [431].

Гіалуронова кислота також має антибактеріальні властивості, тому може допомогти зменшити ризик зараження при безпосередньому нанесенні на відкриті рани [432].

Автори [433] відзначають ефективність дії гіалуронової кислоти у боротьбі iз захворюваннями ясен, прискоренні загоєння після оперативного втручання та усуненні виразок при місцевому застосуванні у ротовій порожнині.

Пектин виконує суттєву роль у стабілізації обміну речовин, знижує вміст холестерину в організмі, покращує периферичний кровообіг, а також перистальтику кишечнику. Значна цінність пектинів полягає у їх сорбційній здатності, тобто можливості зв'язувати і виводити з організму холестерин, радіонукліди, важкі метали (свинець, ртуть, стронцій, кадмій і ін.) і канцерогенні речовини. Пектини сприяють загоєнню слизової оболонки кишечника при іiі пошкодженні. До складу нормальної мікрофлори кишечника входить кілька сотень видів бактерій. Частина 3 них засвоюється поживні речовини за допомогою біохімічних процесів гниття i бродіння. Пектини пригнічують життєдіяльність цих мікроорганізмів, що сприяє нормалізації складу кишкової мікрофлори. [434]. 
SCIENTIFIC FOUNDATIONS OF SOLVING ENGINEERING TASKS AND PROBLEMS

Важливо відмітити суттєве значення вживання продукції, до складу якої входять пектинові уронові кислоти в профілактиці ожиріння:

- знижують час надходження їжі в ШКТ;

- викликають відчуттся насичення, як результат пригнічення апетиту та допомогають запобігти переїданню;

- сприяють зниженню калорійності їжі;

- знижують в жировій тканині синтез жирів завдяки впливу на вуглеводний та жировий обмін.

Альгінати володіють антипухлинною активністю, а також сприяють зниженню апетиту, допомагають запобігти переїданню, широко застосовуються при лікуванні надмірної ваги та ожиріння, сприяють зниженню кількості ліпідів i холестерину в крові, засвоєнню поживних речовин, виведенню важкі металів і радіонуклідів

Солі альгінової кислоти нешкідливі для організму, володіють антимікробними властивостями, підтримують основну здорову мікрофлору кишечника i пригнічують діяльність хвороботворних бактерій, надають обволікаючу дію.

Альгінатні уронові кислоти також мають комплексоутворюючу здатність, зв'язучи і безпечно виводячи з організму важкі метали, токсичні і радіоактивні речовини, утворюючи з ними комплекси [435].

\section{Дослідження принципів утворення гідрогелів на основі уронатних полісахаридів}

На сьогодні квантово-хімічне моделювання дозволило пояснити принципи утворення гідрогелів на основі уронатних полісахаридів та розробити матриці для іммобілізації біологічно активних речовин 3 метою зниження їх реакційної здатності у середовищі шлунку та поліпшення процесів всмоктування у відділі тонкого кишечника [436]. 
SCIENTIFIC FOUNDATIONS OF SOLVING ENGINEERING TASKS AND PROBLEMS

На рис. 1.6, 1.7, 1.8 та 1.9 наведено поетапну реалізація хімічного потенціалу глюкуронової кислоти (рис. 6), як у складі гліциризину (рис. 7), так і складі ксантану (рис. 8) і гіалуронової кислоти (рис. 9).

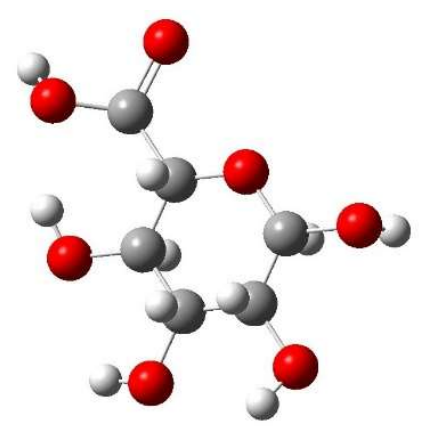

Рис. 6 Квантово-хімічна модель глюкуронової кислоти

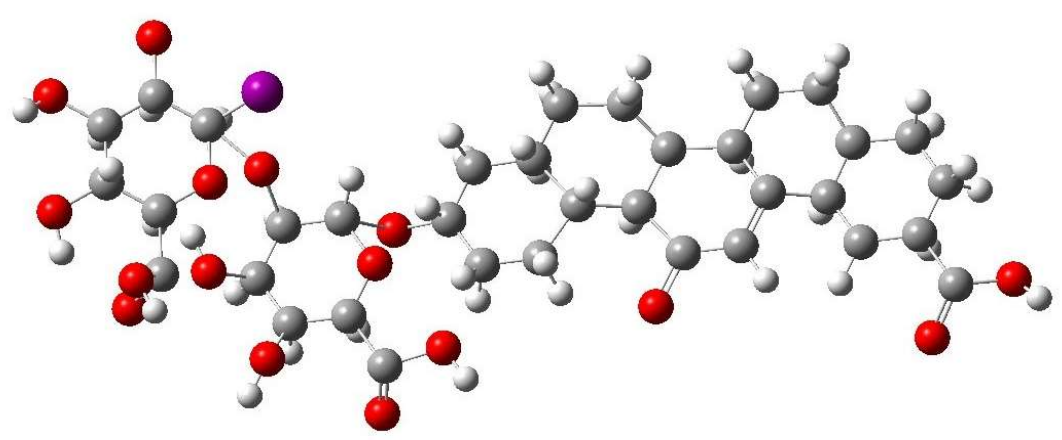

Рис. 7 Квантово-хімічна модель гліциризину

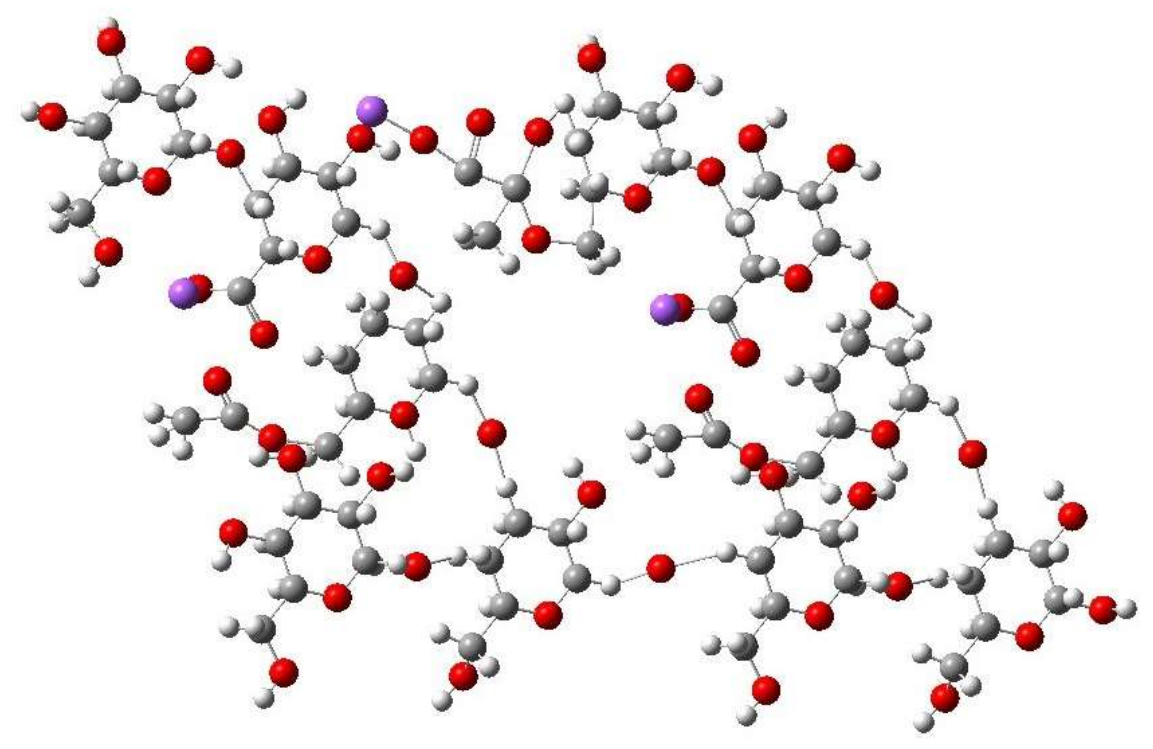

Рис. 8 Квантово-хімічна модель димеру ксантана 


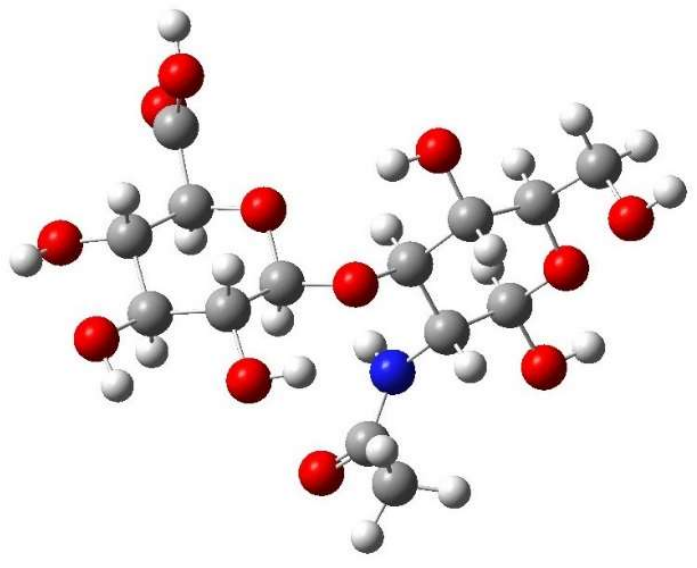

Рис. 9 Мономер гіалуронової кислоти

3 рис. 6, 7, 8 та 9 видно точки зшивання низько- та високомлекулярних сполук під впливом іонної сили розчинника і в присутності ініціаторів кроссополімеризації: біологічно активних речовин з високим хімічним потенціалом та /або лікарських препаратів. За результатами аналізу моделей також було визначено кількість місць реалізації водневого та вандерваальсового зв'язків для кожної структури. Кількість таких міст та просторове розташування дозволяє прогнозувати утворення "ніш" та можливість їх заповнення біологічно активними речовинами та/або лікарськими препаратами з метою зниження їх реакційної здатності у відділах шлунку та збереження хімічного потенціалу до місць їх повного засвоєння - тонкого кишечника.

У наш час значної популярності набуває вивчення полісахаридних композицій на основі альгінату натрію і пектину з іншими полісахаридами. Більш детальне визначення особливостей структур молекулярних комплексів, що реалізовано в системі «уронатні полісахариди $-\mathrm{Ca}^{2+}{ }^{\star} »$ можливе за допомогою методу квантово-хімічного моделювання.

Квантово-хімічне моделювання - це спосіб одержання електронної енергії молекули і їі хвильової функції, що не залежить від розміру і структури макромолекули. 
SCIENTIFIC FOUNDATIONS OF SOLVING ENGINEERING TASKS AND PROBLEMS

Перед початком побудови квантово-хімічної моделі необхідно врахувати

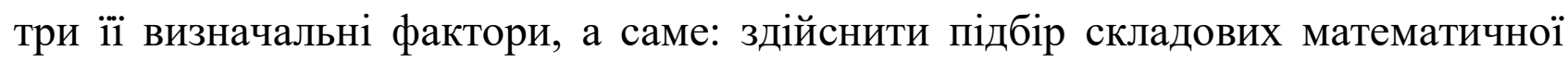
моделі, провести процедуру рішення і обрати атомний базис. Тем самим задать спосіб одержання електронної енергії і хвильової функції [437].

Зокрема, авторами [438] було змодельовано процес іонотропного гелеутворення в системах уронатних полісахаридів (альгінату натрію високогулуронатного і пектину низькоетерефікованого) з кальцієм.

Розрахунок взаємодії активних функціональних груп уронатних полісахаридів з іоном кальцію показує можливість проходження даного процесу 3 утворенням хелатних комплексів кальцій-гулуронатного $\left(\mathrm{CaGul}_{4}\right)$, кальцій-

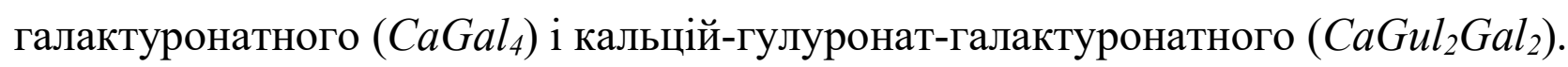

Процес взаємодії здійснюється за рахунок хімічного зв'язування карбоксильних і гідроксильних груп уронатних полісахаридів з іоном кальцію. Встановлено, що кальцій-гулуронатний комплекс має вісім центрів зв'язування 3 кальцієм, a комплекси кальцій-галактуронатний $\mathrm{i}$ кальцій-гулуронатгалактуронатний мають по чотири центру зв'язування.

На підставі цього були одержані квантово-хімічні моделі $\mathrm{CaGal}_{4}, \mathrm{CaGul}_{4}$, $\mathrm{CaGul}_{2} \mathrm{Gal}_{2}$, що представлені на рисунку 10 а-в.

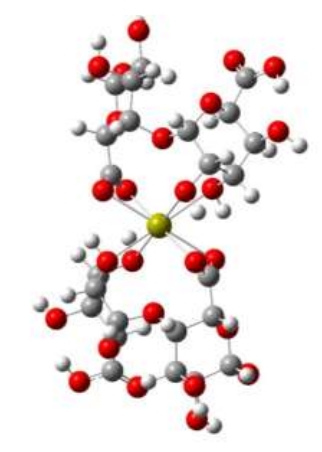

$a$

$\sigma$

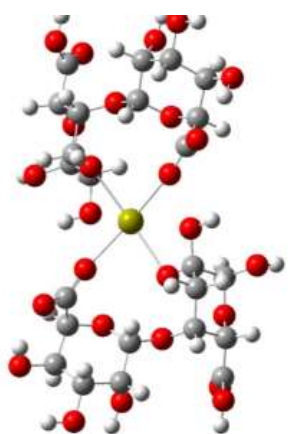

B

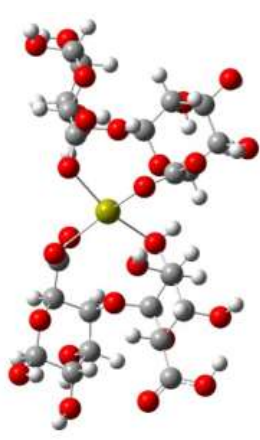

Рис. 10 Моделі стійких кальцій-уронатних систем: а - кальцій тетрагулуронат $\left(\mathrm{CaGul}_{4}\right) ;$ б - кальцій тетрагалактуронат $\left(\mathrm{CaGal}_{4}\right)$; в - кальций дигулуронатдигалактуронат $\left(\mathrm{CaGul}_{2} \mathrm{Gal}_{2}\right)$ 
SCIENTIFIC FOUNDATIONS OF SOLVING ENGINEERING TASKS AND PROBLEMS

Наведені зображення підтверджують унікальність рішення рівняння Шредингера для заданной конфігурації ядер, електронного і спинового стану молекули. Таке рішенння є максимально наближеним до комплексів альгінатпектин-кальцієвих. Крім цього представлені модели прийнятні до систем більшого розміру, що враховують також довільні молекулярні структури.

В табл. 1 наведено геометричні параметри хелатних комплексів системи «уронатні полісахариди - $\mathrm{Ca}^{2+}$ », виділені 3 Z-матриць для оптимізованих молекул $\mathrm{CaGal}_{4}, \mathrm{CaGul}, \mathrm{CaGul}_{2} \mathrm{Gal}_{2}$. В подальшому за допомогою теорії функціоналу густини в наближенні B3LYP з подальшими модифікаціями: M06, М062Х було вивчено особливості конформаційних перетворень комплексів уронатних полісахаридів із кальцієм.

Як геометричні параметри було розглянуто довжину зв'язків, торсійні кути, валентні кути.

Таблиця 1. Геометричні параметри хелатних комплексів системи «уронатні полісахариди $-\mathrm{Ca}^{2+}{ }_{\text {» }}$

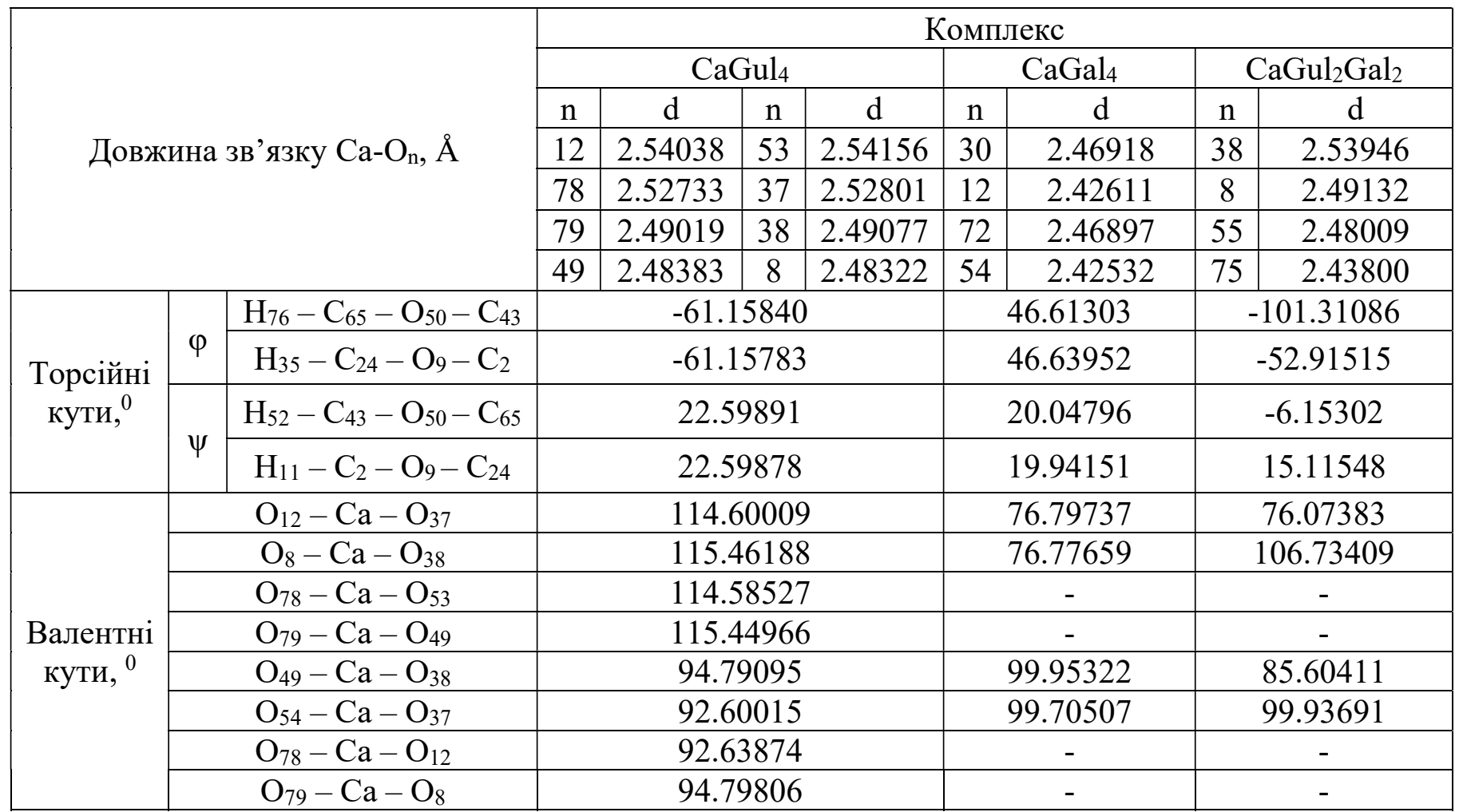


Говорячи про побудову макромолекулярних структур, зокрема уронатних полісахаридів, варто відмітити, що в таблиці 1.1 наглядно представлені характеристики комплексів: дожини координаційних зв'язкыв іону кальцію 3 полісахаридами, торсійні і валентні кути.

Принципово важливим для розуміння хімізму процесів іонотропного гелеутворення в системах таких полісахаридів, як пектин низькоетерифікований амідований і альгінат натрію високогулуронатний, а також їх композиції, $є$ просторове розташування безлічі атомів у даних системах; величина i розташування довжин зв'язків; значення торсіонних і валентних кутів.

Bсе це в сукупності, дозволяє оцінити хімічну активність фрагментів структур макромолекул у разі протікання хімічних процесів іонотропного гелеутворення; дає можливість спрогнозувати кількість зовнішньозв'язаної води, розрахувати оптимальні співвідношення речовин для складання раціональних рецептур харчових продуктів.

На підставі отриманих моделей і їх геометричних характеристик було встановлено факт протікання процесу іонотропного гелеутворення в комбінованій системі «альгінат-пектин-Са». В цьому випадку, утворився хелатний комплекс $\mathrm{CaGul}_{2} \mathrm{Gal}_{2}$, стійкий в ході зберігання, більш пластичний і м'який на відміну від $\mathrm{CaGul}_{4}$ і міцніший на відміну від $\mathrm{CaGal}_{4}$.

\section{Перспективи використання уронатних полісахаридів та їх комплексів у технології харчових продуктів}

Гелі на основі уронатних полісахаридів володіють низкою цінних технологічних властивостей, у зв'язку з чим і користуються значним попитом у різних галузях харчової промисловості.

Широкого застосування набули дані системи в технології десертної продукції, зокрема в технології солодких страв із використанням капсульованих продуктів з пробіотичними мікроорганізмами [439]. Попередньо активовані біфідобактеріï Bifidobacterium lactis BВ 12 були поміщені у капсулу 3 кислотостійкою оболонкою на основі альгінату натрію, що дозволило отримати 
напівфабрикат «Продукт капсульований з пробіотичними мікроорганізмами», який дозволяє уникнути небажаних втрат пробіотичних мікроорганізмів під час їх споживання в складі харчових продуктів. На підставі цього були розроблені рецептурний склад і принципові технологічні схеми виробництва мусу яблучного на крупі манній, самбуку яблучного, крему ванільного 3 напівфабрикатом «Продукт капсульований з пробіотичними мікроорганізмами», що виявили високі показники безпеки та органолептичної привабливості і можуть бути рекомендовані в оздоровчо-профілактичному харчуванні [440].

Було розроблене желе плодово-ягідне на основі напівфабрикатів желюючих [441], реалізуючи метод іонотропного гелеутворення в системі низькоетерифікованого пектину та іонів $\mathrm{Ca}^{2+}$. Продукція представлена желе плодово-ягідним «ПіК» (апельсиновий, вишневий та лимонний) - на основі сухих концентратів соків, «ПіК Преміум» (апельсиновий, вишневий та лимонний) - на основі рідких концентратів соків, «ПіК Преміум Фреш» (апельсиновий, вишневий та лимонний) - на основі натуральної плодово-ягідної сировини.

На основі трифакторної системи «альгінат натрію-пробіотичні організмицитрусові плоди» було запропоновано функціональний харчовий продукт і3 високою концентрацією вітамінів та антиоксидантів цитрусових плодів, із радіопротекторними властивостями альгінату натрію та імуностимулюючою функцією, завдяки вмісту пробіотичних мікроорганізмів, що регулюють роботу шлунково-кишкового тракту людини [442].

3 урахуванням тенденцій щодо раціоналізації технології та складу шоколадних мас відповідно до потреби споживачів, було вдосконалено технологію шоколадних виробів на основі молочного шоколаду шляхом збагачення шоколадних виробів білковим гідролізатом та сумішами уронатних полісахаридів (альгінату натрію та низькоетерифікованого амідованого пектину) [443]. Збагачувальні компоненти - це гелеподібні покриття, які перетворюються на тонкі плівки, які біологічно розкладаються в організмі людини під дією 
корисних кишкових бактерій. Це дозволяє отримувати продукти у плівковому покритті з заданими органолептичними властивостями.

Такий підхід дозволяє відкрити нові властивості готової продукції, поліпшити iї органолептичні властивості, продовжити термін зберігання та зменшити кількість пластику, що використовується під час пакування.

Гелі харчові плівкоутворюючі на основі уронатних полісахаридів (альгінату натрію, нізькоетерифікованого амідованого пектину та ксантану) представляють собою перспективний матеріал для використання у як харчові покриття, в тому числі глазурі. Це стало підгрунтям для створення глазурей із гідрогелів на основі уронатних полісахаридів та технології печива галетного «Марія» у плівкоподібній оболонці із заданими фізичними та структурно-механічними характеристиками [444].

Досить актуальним $є$ можливість використання гелів харчових плівкоутворюючих на основі суміші уронатних полісахаридів (альгінату натрію та пектину) у складі снекової продукції, зокрема оболонок для рибних закусок [445].

Такий технологічний підхід дає можливість подовжити термін зберігання даних харчових продуктів, а також підвищити їх харчову цінність. Уронатні полісахариди володіють здатністю до зв'язування важких металів, виведення токсинів, відновлення складу мікрофлори товстого кишечнику та дозволяють впровадити технологію виробництва рибних закусок (паличок) без використання штучних оболонок, замінивши їх плівками на основі уронатних полісахаридів, що володіють гарними пребіотичними властивостями та запобігають накопиченню патогенних мікроорганізмів.

3 метою підвищення харчової цінності м’ясної снекової продукції було запропоновано покращення складу маринадів на основі розчину уронатних полісахаридів маслом амаранту і сумішей для ін'єктування - гідролизатом протеїну амаранту [446]. Це дозволяє отримувати м'ясні системи зі стабільними структурними і механічними характеристиками. 
Таким чином, сполуки, до складу яких входить глюкуронова кислота, ксантан, гліциризин, гіалуронова кислота, володіють широким спектром фізикотехнологічних властивостей у складі композиційних гідрогелів. Вони також $\epsilon$ основною для створення продуктів для здоров'я людини (продукти харчування, фармацевтичні, лікарські, косметичні засоби).

Виначення координаційної взаємодії таких комплексів глюкуронових кислот сприяє об'єктивному вибору видів уронатних полісахаридів для промислової переробки з урахуванням їх фізико-хімічних властивостей. 